\title{
A Universidade e os jovens
}

\section{Elísio Estanque e João Arriscado Nunes}

\section{OpenEdition}

\section{Journals}

\section{Edição electrónica}

URL: http://journals.openedition.org/rccs/1150

DOI: $10.4000 /$ rccs. 1150

ISSN: 2182-7435

\section{Editora}

Centro de Estudos Sociais da Universidade de Coimbra

Edição impressa

Data de publição: 1 outubro 2003

Paginação: 03-04

ISSN: 0254-1106

\section{Refêrencia eletrónica}

Elísio Estanque e João Arriscado Nunes, «A Universidade e os jovens », Revista Crítica de Ciências

Sociais [Online], 66 | 2003, posto online no dia 01 outubro 2012, consultado o 22 setembro 2020. URL : http://journals.openedition.org/rccs/1150 ; DOl : https://doi.org/10.4000/rccs.1150 


\section{A Universidade e os jovens}

Num momento em que o ensino superior e as politicas educativas ocupam o centro de tantas controvérsias, é importante repensarmos o papel das instituições universitárias e da juventude estudantil no quadro das transformações sociais e políticas das últimas décadas.

O presente volume da Revista Crítica de Ciências Sociais é dedicado ao tema «A Universidade e os jovens». Na verdade, pode dizer-se que se trata, não de um mas de dois temas, visto que apenas em parte as duas realidades são sobreponiveis. Porém, a sua ligação é tão estreita que seria difícil falar de um sem fazer referência ao outro. A universidade não só é composta por milhares de jovens estudantes como, enquanto parte integrante do sistema de educação, é largamente responsável pela emergência dos "jovens" enquanto novo "actor" social que - sobretudo desde a segunda metade do século XX - passou a ocupar um lugar de destaque nas principais mudanças sociopoliticas das sociedades contemporâneas.

Sem dúvida que, para além da sua importância social, política, cultural, etc., a 'juventude' não é senão uma palavra, como em tempos escreveu Bourdieu. Ou seja, não há uma, mas muitas e variadas "condições juvenis", pelo que seria uma grosseira mistificação confundir-se o ambiente estudantil universitário com outros contextos onde predominam jovens, como por exemplo o trabalho fabril, o desporto, o lazer, a delinquência, a toxicodependência, etc. Nessa medida, importa esclarecer que este volume temático não pretendeu tratar a diversidade de fenómenos sociais para que remete a temática dos "jovens", mas apenas, no âmbito do tema proposto, analisar um segmento específico da população jovem - os estudantes do ensino superior.

O primeiro artigo (de autoria dos organizadores deste volume) apresenta alguns dos problemas e desafios que se colocam ao sistema universitário na actualidade, colocando a ênfase na recomposição social dos estudantes, das suas origens e das suas subjectividades e discutindo, a partir dos resultados de um inquérito, o caso da Universidade de Coimbra, em especial alguns dos problemas da relação entre a sociedade e a Universidade e os desafios que o século XXI lhes vem colocar.

$O$ artigo colectivo de Fernando Luís Machado e outros aborda também a recomposição da população estudantil universitária, e propõe-se, por um lado, discutir modelos de análise das teorias das classes e, por outro, analisar 
resultados de um inquérito nacional aplicado aos estudantes, em que as questões da abertura da Universidade à classe trabalhadora, das orientações subjectivas dos estudantes e da desigualdade sexual constituem dimensões em estudo.

Se nos primeiros dois textos a sociedade, os estudantes e o ensino superior são colocados em articulação, nos dois seguintes são os jovens universitários que estão mais abertamente no centro da reflexão.

Assim, o artigo de Aníbal Frias ocupa-se dos rituais da praxe e das festas estudantis de Coimbra, desenvolvendo uma análise sócio-antropológica desta questão, do ponto de vista do seu enquadramento cultural e histórico. Algumas das discussões em torno da violência que estes rituais por vezes envolvem, bem como o problema da diferença sexual, são abordados no contexto de uma cultura universitária cujo estatuto de prestígio cresceu ao longo de sete séculos de bistória e em estreita ligação entre os poderes académico, institucional, e eclesiástico.

O texto de Marcos Mesquita centra-se igualmente nos estudantes, mas neste caso no movimento estudantil brasileiro. A partir de uma experiência de observação-participação, o autor traça-nos um breve retrato das diferenças, das contradições e das polémicas de natureza político-ideológica que atravessaram os protestos e a acção política dos estudantes daquele país, sobretudo ao longo da última década do século passado.

Finalmente, o artigo de Rui Bebiano interpela-nos também a propósito dos movimentos estudantis e do passado histórico da Universidade de Coimbra a este propósito, chamando a atenção para a importância da memória e para a preocupante facilidade com que ela se tende a esbater no activismo estudantil mais recente.

O objectivo principal deste volume foi, pois, contribuir para aprofundar o conhecimento, não apenas da Universidade, mas da "experiência universitária". Para tanto, propusemos um conjunto de textos que transcendem a estrita visão institucional do ensino superior, procurando dar visibilidade a contextos, factores estruturais e subjectividades da vida estudantil que, no seu conjunto, configuram os efeitos e implicações do sistema universitário. Esperamos que a sua leitura possa não só enriquecer a compreensão dos problemas do campo académico, mas também contribuir para clarificar as múltiplas implicações e interdependências entre a Universidade e a sociedade. Esta é, com efeito, uma condição decisiva para que do seu enriquecimento recíproco possa projectar-se uma efectiva "sociedade do conbecimento". Uma sociedade fundada no acesso democrático ao saber científico e ao ensino de qualidade onde, cada vez mais, se reforcem os direitos e a cidadania, se combata as desigualdades sociais e se promova o desenvolvimento sustentável.

Elísio Estanque

João Arriscado Nunes 